Portland State University

PDXScholar

Fall 1-24-2014

\title{
Project NANO: Will Allowing High School Students To Use Research Grade Scanning Electron Microscopes Increase Their Interest in Science?
}

Leslie TenEyck Smith

Portland State University

Follow this and additional works at: https://pdxscholar.library.pdx.edu/open_access_etds

Part of the Educational Methods Commons, Nanoscience and Nanotechnology Commons, and the Science and Mathematics Education Commons

Let us know how access to this document benefits you.

\section{Recommended Citation}

Smith, Leslie TenEyck, "Project NANO: Will Allowing High School Students To Use Research Grade Scanning Electron Microscopes Increase Their Interest in Science?" (2014). Dissertations and Theses. Paper 1549.

https://doi.org/10.15760/etd.1548

This Thesis is brought to you for free and open access. It has been accepted for inclusion in Dissertations and Theses by an authorized administrator of PDXScholar. Please contact us if we can make this document more accessible: pdxscholar@pdx.edu. 
Project NANO: Will Allowing High School Students To Use Research Grade Scanning Electron Microscopes Increase Their Interest in Science?

\section{by}

Leslie TenEyck Smith

A thesis submitted in partial fulfillment of the requirements for the degree of

Master of Science in Teaching in

General Science

Thesis Committee:

Liza Finkel, Chair

Michael Flower

Melissa Potter

Kate Dean

Portland State University

2013 
(C) Leslie TenEyck Smith 


\begin{abstract}
$\underline{\text { Abstract }}$
In this study, one AP Biology curriculum unit and one general Biology curriculum unit that included tabletop Scanning Electron Microscope (SEM) technology provided by Project NANO, a grant-funded, collaborative initiative designed to integrate cutting-edge nanotechnology into high school classrooms were implemented at a public high school in rural Oregon. Nine students participated in the AP unit and 52 students participated in the general Biology unit. Each student completed an opinion-based pre and post survey to determine if using the SEM as a part of the curriculum unit had an impact on his or her interest in science or in nanoscience. Interviews were conducted to add to the data. The results indicate that using the SEM can increase a student's interest in science. Recommendations for improving student experience were identified.
\end{abstract}


Table of Contents

$\begin{array}{lr}\text { Abstract } & \text { i } \\ \text { List of Tables } & \text { ii } \\ \text { List of Figures } & \text { iii } \\ \text { Chapter } 1 & \\ \text { Introduction } & 1\end{array}$

Chapter 2

Review of Literature $\quad 5$

Chapter 3

Methods 11

Chapter 4

Findings 21

Chapter 5

Discussion $\quad 41$

Chapter 6

Limitations and Recommendations $\quad 44$

Chapter 7

Further Studies $\quad 46$

$\begin{array}{ll}\text { References } & 48\end{array}$

Appendices
A. Instruments
50
B. Research Approval Documents 53
C. Curriculum 


\section{List of Tables}

Table 1: Illustrative representation of study design 11

Table 2: Percentage of students in each ethnic group at EHS 12

Table 3: Percentage of students enrolled in special service programs at EHS 13

Table 4: Daily schedule of EHS' primary Biology teacher 14

Table 5: Summary of interview data 40 


\section{List of Figures}

Figure 1: Impact on Interest in Science 23

Figure 2: Impact on Each Category of Interest in Science 24

Figure 3: Impact on Interest in Science by Academic Performance

Figure 4: Impact on Each Category of Interest in Science by Academic Performance

Figure 5: Experiences with an SEM

Figure 6: Experiences with an SEM by Academic Performance 


\section{Chapter 1: Introduction}

Maintaining our leadership in research and technology is crucial to America's success. But if we want to win the future -- if we want innovation to produce jobs in America and not overseas -- then we also have to win the race to educate our kids. - President Barak Obama, State of the Union Address, January 25, 2011 President Barack Obama and Secretary of Education Arne Duncan believe that the future economic strength of our nation depends on improving the quality of education in science, technology, engineering, and mathematics, otherwise known as STEM education (Roco, 2003). Unfortunately, students are not making critical gains in standardized test scores (Gonzales et al., 2004), science education is not addressing the critical need to prepare scientists to expand U.S. scientific research efforts (Yager, 2003), and as a country, we are not making progress in developing a scientifically literate citizenry (National Science Board, 2002). The National Math and Science Initiative (2005), a consortium of educators, government leaders, and researchers provide the following examples that support the need to call immediate attention to this issue:

- U.S. students recently finished $14^{\text {th }}$ in science and $19^{\text {th }}$ in math in a ranking of 31 countries by the Organization for Economic Cooperation and Development

- Only 29 percent of American fourth grade students, a third of eighth grade students, and barely 18 percent of $12^{\text {th }}$ grade students perform at or above the proficient level in science 
- In Business Week's ranking of the world's information-technology companies, only one of the top 10 is based in the U.S.

- Of the new R\&D sites planned for construction in the next three years by 177 companies queried in a survey, 77 percent are to be built in China or India.

The National Science Foundation (NSF) and the National Nanotechnology Institute (NNI) are also increasingly concerned that in the near future the U.S. will not have the workforce or intellectual capacity to compete in worldwide nanoscience efforts (National Science Board, 2010). The term 'nano' refers to the nanometric scale, nanoscience and nanotechnology are disciplines that experiment and engineer on this scale. The senior advisor for nanotechnology at NSF, Mihali C. Roco (2003), estimates that by 2015 there will be a need for a workforce of approximately 2 million scientists and researchers in the nanoscience field. This number will only increase in the following years.

This demand stems in part from the fact that our society is currently experiencing a dramatic shift in the science and technology that people interact with everyday. In particular, ordinary citizens interact with nanoscience and nanotechnology in contexts including food, medicine, fabric, electronics, cosmetics, cars, homes, and gardens much more frequently than at any time in the past. According to Hignent and Albe (2010) nanoscience, and nanotechnology are: 
1) intrinsically interdisciplinary, and

2) part of a large group of technologies currently making a convergence.

Other countries have already begun preparing for a nano-focused future by implementing nanoscience initiatives intended to develop their citizens' capacity for undertaking nanoscience research and careers. The European Commission (2005) has defined an action plan for Europe to promote growth and jobs in nanotechnology through interdisciplinary education and training; the German Federal Ministry of Education and Research (2011) has developed a national strategy to promote education, research, and innovation in nanotechnology; and the Nanotechnology Researchers Network Center of Japan (2006) has organized a number of nanotechnology schools to train young researchers. These extensive world-wide efforts clearly demonstrate that it is the responsibility of national, state and local education leadership in the United States to prepare a much larger cross-section of the U.S. population with the science and engineering knowledge necessary to function in a society permeated with nanoscience and nanotechnology and to maintain the momentum of discovery and innovation that will sustain the nation's economic prosperity.

One effort designed to answer the call for training our youth in nanoscience is a project funded mainly by a grant from the M.J. Murdock Charitable Trust that focuses on secondary and post-secondary teachers called Project NANO. Project NANO is a collaborative effort between university and high school faculty that was designed to increase K-12 students' understanding of nanoscale phenomena through inquiry-based 
activities that use research-grade optical and electron microscopes as investigative tools. The project aims to positively impact the interest in science and science career readiness of middle, high school, and college students by providing interactive and engaging curriculum and experiences that connect structure and function, science inquiry and engineering design -- all key themes in state and federal science standards and all themes appropriate to study using nanotechnology.

Each of the microscopes utilized by Project NANO is capable of producing high quality digital images that provide visual data for the students' inquiry projects. As a part of the project, data is collected on impacts of participating in the program for both teacher and students. Teachers participate in a summer professional development workshop where they learn to use nano-imaging technology and develop curriculum using that technology for implementation in their classrooms. Teacher participants then "sign out" the tabletop SEM for a two to three week period of use in their classroom during the following school year. Teachers are evaluated for gains in content and pedagogical knowledge and skills as a result of participation in Project NANO professional development. Students are evaluated on content gains as the result of their participation in curriculum units designed and implemented by their teachers. Student content gains are measured through completion of an inquiry work sample; changes in their dispositions toward nanoscience and science in general are measured by responses to a pre/post survey. This pre/post survey is still under development and this project is intended to be 
a pilot for a potential instrument that can be used to understand the impact of Project NANO-based curriculum units on students' dispositions towards science.

As a part of this larger project, the purpose of this study was to introduce high school age students to nanotechnology and nanoscience with the goal of sparking interest in science. Ultimately, the author believes that this interest may lead to students choosing a career in a STEM field (Maltese and Tai, 2009). Through this study, the author aimed to answer the question: Will allowing students access to a hands-on nanotechnology experience increase their interest in science? The independent variable in this study is participation in a curriculum unit that incorporates access to, and use of, a tabletop Scanning Electron Microscope (SEM). The dependent variable is interest in science as shown through three categories of interest: i) general interest in science, ii) interest in microscopes, and iii) interest in nanoscience. The dependent variable was measured using four-point likert-type surveys administered before and after participation in a biology curriculum unit that included use of a tabletop SEM provided by Project NANO. Supplementary data on student experiences was recorded using one-on-one interviews. Sixty-one students participated: 9 AP Biology students and 52 general Biology students.

\section{Chapter 2: Review of Literature}

Research relevant to this study can be categorized into three areas. The first includes research on the impact of interest in science on students' likelihood to pursue 
STEM careers. The second includes research on the use of nanoscience as a means of increasing interest in STEM disciplines. The third category includes research that addresses the feasibility of incorporating nanotechnology into the secondary classroom. This is a key part of the literature as this study aims to integrate nanotechnology into a public high school classroom that has little to no funding for advanced scientific tools.

\section{Interest in STEM disciplines as a tool for motivating students to enroll in STEM courses and seek STEM careers.}

Several researchers have found that establishing an interest in science is likely to lead to an individual choosing to explore science further either through education or a career in the field. Simpkins et al., (2006) found this to be especially true for school-age students. These researchers conducted a longitudinal study that addressed the association between youths' out-of-school activities and course enrollment in the domains of math and science in order to determine factors that contributed to the persistence of students in math and science disciplines. Participants were surveyed during the $5^{\text {th }}$ grade, the $6^{\text {th }}$ grade, and the $10^{\text {th }}$ grade. The participants who showed interest in or participated in an activity associated with the domains of math or science at an early age were more likely to continue to pursue this endeavor through high school courses. Lubben et al., (2010) furthered this research on persistence in a study of older students. They conducted a case study in South Africa that examined the factors influencing students' enrollment in an 
undergraduate science program. Through their investigation, the authors found two primary forces driving the continued enrollment in the undergraduate science programs: 1) interest in the subject, and 2) personal STEM career goals. These studies clearly demonstrate the impact that interest in science can have on decisions to receive training in STEM fields. Individuals such as the participants in these studies will be the STEM workforces in the future.

An argument can be made that the dominant force behind persistent enrollment in STEM courses is mandatory enrollment in science at the High School level as opposed to genuine interest in the field. Maltese and Tai (2009) investigated this claim by studying whether the primary driving force that leads students to earn degrees in STEM fields is interest in science or mandatory enrollment in science courses. They examined this by correlating surveys on interest in science conducted during the eighth grade to transcripts of the same students later in their educational careers. The results show that students who indicated that they were interested in a science career or believed science would be useful in their future were more likely to earn degrees in STEM fields. Since these indications of interest were communicated prior to their enrollment in high school courses, the researchers concluded that it is interest that drives enrollment, and not the reverse. While some students become interested in STEM when they reach college, the data from this study indicate that many students make their major decisions before they ever arrive on college or university campuses. This suggests that attention to increasing middle and high school students' interest in science and mathematics and demonstrating to students the 
utility of these subjects in their current and future roles may pay great dividends in building the STEM workforce.

\section{Nanotechnology as a tool to increase interest in science.}

A great hurdle in cultivating interest in science in students is determining an effective method of doing so. A medium that is engaging, interesting and relevant is necessary to achieve this goal. Hsi et al. (2006) identify nanotechnology as one of the possible frameworks that could successfully act as a catalyst for increasing interest and enrollment in science education. They argue that nanoscience has become so fundamental to society that implementation of high quality nanoscience curriculum is one of the best ways to capture the imagination of new generations of diverse communities of youth. Part of the confidence in the success of nanoscience is because nanoscience, as a field of study, incorporates a conceptual framework that is responsive to an interdisciplinary, system-oriented ways of doing and using science. These fundamental characteristics of nanoscience are exactly what a coherent curriculum vision needs in order to seize the curiosity and fascination of today's youth.

Many researchers agree with this compelling argument made by Hsi et al. (2006). The subsequent action necessary to support this claim is to investigate the affect of nanoscience in the classroom. Hingnant and Albe (2010) compiled data on recent studies investigating the introduction of nanosciences and nanotechnologies (referred to as 
'nanos') into secondary education. Every author involved in the review considered the introduction of nanos in science curricula worth studying and aimed at influencing, orienting, or changing the learning and teaching of nanosciences and nanotechnologies. A plethora of data presented evidence for a positive effect on the attitudes of high school students toward science and towards the idea of a career in science as a direct result of interacting with nanos. In addition, the authors found common arguments for the eminent need to integrate nanos into secondary curricula. The first argument points to the looming shortage of nanoscientists and nanotechnologists, attesting that it is a matter of American interest to ensure that a sufficient number of nanoworkers be trained. The second argument is founded on the need to provide every secondary student with the opportunity to acquire 'nanoscientific literacy'. This argument is fueled by the seemingly omnipresent nanotechnologies in our current societies and urges the reader that it is the duty of the schools to provide the future citizens of this nano-filled society with the tools to make informed decisions.

\section{Feasibility of nanoscience in the secondary classroom.}

One of the major impediments in implementing nanoscience curricula at the secondary level is the level of financial investment required to supply the nanotools. The tools used in the field of nanoscience are highly advanced, powerful and quite new; all of these factors make them expensive and far beyond the budgets of most public schools. Jones et al. (2003) attempted to evade this constraint by using a remote-controlled 
Atomic Force Microscope (AFM). While these tools are still costly to rent for a period of time, it is much less of a burden than purchasing a nanotool. With the tools lined up, the authors investigated the affect that using the microscope had on high school students' understanding of nanotechnology and careers in science. The data revealed positive results: all participants experienced an increase in comprehension of the scientific topic addressed and gained a more accurate view of microscopy techniques and careers in science. Unmistakably, this study demonstrates that even the less costly alternatives to nanotools are effective in promoting interest and understanding of science and technology.

\section{Summary}

These studies demonstrate that interest in science is a reliable measure for the probability of an individual pursuing a career in a STEM field and that nanoscience is an effective tool for increasing interest in science. They also demonstrate that the largest barrier preventing the incorporation of nanotechnology into the secondary classroom can be sidestepped with alternative tools and still produce a positive impact on participants. However, no studies have been published that examine the alternative, inexpensive tabletop Scanning Electron Microscope (SEM) as an effective nanoscience tool in the secondary classroom. This study aims to contribute to the literature by investigating the affect of using a tabletop SEM on student interest in science. 


\section{Chapter 3: Method}

The following section describes the methods used for this study. It includes a description of the participants, the setting in which the study was carried out, the instruments used, and the procedure used to collect and analyze the data.

\section{Overview}

This study was designed to determine if using a Scanning Electron Microscope (SEM) would increase high school students' interest in science. To understand the affect of using the SEM on their interest, students in two high school science classes (AP Biology and General Biology) participated in Biology curriculum units that incorporated the use of a tabletop SEM, a research grade nanotechnology tool. Evidence of interest in science before and after participation was gathered to determine if there was a correlation between participation in using the SEM and interest in science. Data was collected using pre and post surveys and interviews focusing on interest in science.

Table 1: Illustrative representation of study design.

\begin{tabular}{|l|c|c|c|}
\hline & Pre Unit & Curriculum Unit & Post Unit \\
\hline Group 1 & $\mathrm{O}_{\mathrm{PR}}$ & $\mathrm{X}_{1}$ & $\mathrm{O}_{\mathrm{PO}}, \mathrm{I}$ \\
\hline Group 2 & $\mathrm{O}_{\mathrm{PR}}$ & $\mathrm{X}_{2}$ & $\mathrm{O}_{\mathrm{PO}}, \mathrm{I}$ \\
\hline
\end{tabular}

Group 1 = Students enrolled in the AP Biology Course 
Group 2 = Students enrolled in the general Biology Course

$\mathrm{O}_{\mathrm{PR}}=$ Pre assessment on interest in science

$\mathrm{X}_{1}=$ AP Biology Unit

$\mathrm{X}_{2}=$ General Biology Unit

$\mathrm{O}_{\mathrm{PO}}=$ Post assessment on interest in science

$\mathrm{I}=$ Interviews conducted addressing student experiences

\section{Participants}

This study took place at a public high school in a small, rural town in the NW United States located approximately 30 miles east of a large metropolitan city. This high school was chosen because the study's author completed her student teaching there. The pseudonym Eastland High School (EHS) in the Eastland School District (ESD) has been assigned to maintain confidentiality.

According to statistics reported by ESD, EHS' student population is described in Table 2. These statistics describe EHS as having a majority white student population with very low numbers in the minority groups. The participants in this study reflect the overall school population.

Table 2: Percentage of students in each ethnic group at EHS

\begin{tabular}{|l|c|}
\hline \multicolumn{1}{|c|}{ Ethnic Group } & $\begin{array}{c}\text { Percent of Students } \\
\text { Enrolled at EHS }\end{array}$ \\
\hline Native America & $1.3 \%$ \\
\hline Asian or Pacific Islander & $1 \%$ \\
\hline Black & $0.7 \%$ \\
\hline Hispanic & $8 \%$ \\
\hline
\end{tabular}




\begin{tabular}{|l|c|}
\hline White & $78 \%$ \\
\hline Unclassified & $10.8 \%$ \\
\hline
\end{tabular}

The Eastland School District reports the following program enrollment at EHS (Table 3). This description of the student population is reflected in the population of study participants.

Table 3: Percentage of students enrolled in special service programs at EHS

\begin{tabular}{|l|c|}
\hline Program Enrollments: & School \\
\hline Percent of Students on an IEP & $14 \%$ \\
\hline $\begin{array}{l}\text { Percent of Students in ESL } \\
\text { Programs }\end{array}$ & $4.5 \%$ \\
\hline $\begin{array}{l}\text { Percent Students Receiving Free } \\
\text { and Reduced Lunch }\end{array}$ & $57 \%$ \\
\hline $\begin{array}{l}\text { Percent of Students in TAG } \\
\text { Programs }\end{array}$ & $11 \%$ \\
\hline
\end{tabular}

According to the Oregon Report Card Rating (ODE, 2011), the school's rating is satisfactory. On the Oregon State English/Language Arts test 79\% of students met the target and an additional 5.7\% exceeded. The results on the Oregon state mathematics test showed slightly lower scores with $28.1 \%$ of students not meeting the target. In the category of science, $16.6 \%$ of students who took the Oregon state test exceeded the 
target. However, only $44.4 \%$ fell into the "Met" category, leaving 39.1\% who did not meet the target.

Seven hundred and eighteen students attend the high school. EHS's primary Biology teacher (who served as the study's cooperating teacher during the period including the study) teaches approximately a quarter of the school population at any given time. Her class schedule consists of one period of AP Biology with approximately 15 junior and senior students and four periods of general Biology that include both freshmen, sophomore and junior students each enrolling approximately 25 to 30 students. Table 4 shows the daily schedule of this teacher's classes.

Table 4: Daily schedule of EHS' primary Biology teacher

\begin{tabular}{|c|c|c|}
\hline Period & Allotted Time & Class \\
\hline 1 & $7: 38-8: 28$ & AP Biology \\
\hline 2 & $8: 33-9: 23$ & Biology \\
\hline 3 & $9: 28-10: 20$ & Prep Period \\
\hline 4 & $10: 25-11: 15$ & Biology \\
\hline Lunch & $11: 15-11: 45$ & \\
\hline 5 & $11: 50-12: 40$ & Biology \\
\hline 6 & $12: 45-1: 35$ & Biology \\
\hline 7 & $1: 40-2: 30$ & Agriculture Elective \\
\hline
\end{tabular}


All students enrolled in the five Biology courses participated in the curriculum units that are the focus of this study; all study participants completed a survey on interest in science before and after participation. In addition, nine students enrolled in the general Biology course were interviewed to further explore the impact of their experience using the SEM on their interest in science. These students were selected by random choice within three academic performance categories. Only 61 students ( 9 in the AP course, and 52 in the general Biology courses) completed all documents and instruments necessary to participate in this study.

\section{Instruments}

Pre-unit Survey: A pencil and paper survey was used as the measurement of students' interest in science and nanoscience prior to their completing the biology unit and using the SEM. The author developed the survey with input from Project NANO researchers, the Project NANO program evaluator and the author's research advisor. It was designed to measure the dependent variable: interest in science. The survey consists of ten, four-point, Likert-type statements. Students were instructed to respond to each statement indicating their personal level of agreement with the statement. Face validity was established through review by researchers and evaluators involved in Project NANO and the author's research advisor. 
Post-unit Survey: In addition to asking students to rate the same statements that appeared on the pre-unit survey, five Likert-type statements and one open-response question specific to the experience using the SEM were added to the survey administered after students used the SEM. Face validity of these items was also established through review by researchers and evaluators involved in Project NANO and the author's research advisor.

Interviews: One-on-one interviews were conducted with nine general Biology students at the conclusion of the study to further explore their interest in science and nanoscience as a result of using the SEM as a part of their science class. Students from the general Biology academic performance levels (high, middle, and low as determined by the previous quarter's final grade) were selected to participate in this portion of the data collection. Each student was assigned a random number that was recorded on his or her post survey. These papers were separated into the three academic groups. Each group was spread face down on a table and three papers were chosen at random to determine which students would be interviewed. The author developed the interview questions to address the main research question and the aspects of participation that she was most curious about. The Project NANO evaluator and the author's research advisor approved all questions used in the interview.

\section{Procedure}


During the 4th quarter of the 2012 -- 2011 school year, students who were enrolled in Biology (General Biology or AP Biology) courses at Eastland High School were given the opportunity to use a portable, tabletop SEM as part of a curriculum unit regularly covered in each class. Data on student interest in science was collected before and after students used the SEM via pre and post surveys and one-on-one interviews to determine if including the tabletop SEM in biology curriculum had an affect on students' interest in science.

Before students were given the opportunity to use the SEM, 61 study participants completed the pre-survey on interest in science. Nine of those students participated in an AP Biology curriculum unit on the topic of taxonomy. The other 52 students participated in a general Biology curriculum unit on the topic of genetics. Both units included use of a tabletop SEM as a means of providing a hands-on experience with nanotechnology. The goal of this experience was to increase participants' interest in science.

The SEM was available for student use a total of 15 school days. A total of 91 students used the SEM during this time period. However, only 61 completed the necessary consent forms and all data instruments and therefore were considered participants in this study. Of these 61 students, fifty-two participants used the SEM one time and nine students used it twice when technical complications occurred during their first opportunity. Three of the days that the SEM was available were not regular class meeting days. Each Friday at Eastland High School is a voluntary intervention day, 
during which students sign up to receive extra help and work on projects with specific teachers. These intervention days were valuable in ensuring that the nine participants who experienced technical difficulties during their first use of the tool received a chance to use the tool for a second time.

The SEM arrived on a Monday afternoon. Over the next four days, AP Biology students used it to gather data on a variety of insects collected and provided by the Oregon Department of Agriculture Entomology Department. The author was present during each session and provided direct instruction on how to operate the SEM. AP students used the anatomical data they gathered to identify the family of insect they had chosen. They presented their evidence in the form of a poster that included the SEM images they had acquired.

On the Thursday of this first week, all general Biology students received direct instruction with media supplements provided by Project NANO on how an SEM works and how nanoscience is used in society today. This included three short videos addressing how the SEM works, how the SEM is used in forensic science, and basic operating procedures of the SEM. The researcher then used a PowerPoint presentation to explain the definition of nanoscience and discuss how nanoscience is applied in everyday life. This presentation was put together using resources provided by Project NANO and the National Nanotechnology Initiative. The following Monday, general Biology participants chose partners (with the option of working individually) for the assignment associated 
with using the SEM and began preparing their specimens and collecting data on fruit fly mutations. The students used this data to provide images of a mutation that they had researched using a variety of sources on the Internet. They then used this knowledge and their images to create theoretical scenarios that demonstrate their understanding of inheritance and Mendel's principles.

After the curriculum unit ended each participant completed the post-survey that consisted of the ten statements seen on the pre-survey and the five statements and an open-response question that addressed personal experience with the SEM.

Nine students, three from each academic group, were then chosen to participate in an interview to further explore their experiences with the SEM. To select the interview participants, the identification number of each participant was written on a small piece of paper. These papers were then separated into three categories of academic performance. Students enrolled in the AP course were sorted into the 'Advanced Placement' academic performance group. For the purpose of this study, this group was considered very high performing but time constraints prevented their participation in the interviews. For the students enrolled in the general Biology course, academic performance categories were determined by examining students' Biology grades from the previous quarter. It is critical to recognize that this categorization is based on merit of an entire semester and not necessarily the performance on a single topic. This method also doesn't necessarily reflect the performance during the time period in which this study was conducted. 
Nonetheless, students who earned between 92 and 100 percent during the last quarter were sorted into the 'high-performing' category. Students in the 'middle-performing' group earned between 81 and 91 percent during the last quarter; students placed in the 'low-performing' category earned between 14 and 80 percent during the last quarter. Once separated, three numbers were randomly drawn from each category and those students were asked to participate in interviews.

\section{Data Analysis}

Interest in science was measured using ten statements pertaining to three categories of interest in science: interest in science, interest in microscopes, and interest in nanoscience from the pre and post opinion survey. Students' responses were coded using a scale of 1-4 where 4 correlated to a student strongly agreeing with the statement, 3 correlates with agree, 2 correlates with disagree, and 1 correlates with disagreeing strongly. This data was used to determine the average change in interest for each group analyzed. A change in the average rating of all ten statements for any particular group indicated a change in interest in science. The ten questions were then broken into three 'question categories' to determine if there was a change in interest in a particular focus

(science, microscopes, \& nanoscience). Due to the small sample size of this study, no statistical analysis was applied. 
The differences between the ratings on five additional statements (related specifically to use of the SEM) on the post survey were also compared to further dissect the experiences of the participants. These responses were also compared across academic groups to determine if the SEM had a different affect on students of different academic performance. This data was analyzed by comparing the average score reported on each statement. A score above 2.5 was considered agreement with the statement and a score less than 2.5 was considered as in disagreement. Again, no statistical significance was calculated due to the small number of participants.

The open response answers on the post-unit survey, along with responses to the interview questions, were summarized for the seven students who were selected as interview participants and who had met all qualifications for participating in this study. The purpose of the open response question and the interview questions was to further investigate students' reactions to their experiences using the SEM and to identify improvements that could be made to the project.

\section{Chapter 4: Findings}

This study was guided by the research question: does allowing students access to nanotechnology via an SEM increase their interest in science. The following section addresses findings for this research question. The section is broken into three subsections. The first discusses the change in interest in science as quantified by the pre and post 
surveys. The second describes students' experiences with the SEM as quantified by five additional statements on the post survey that focuses specifically on use of the SEM. The final section is a case-study analysis of seven students' individual experiences with the SEM. The data for the final section was gathered using the open response question on the post assessment and interviews conducted after students used the SEM.

\section{Change in interest}

To determine the affect of using the SEM on this group of students, the average ratings on the pre and post survey were compared to determine a change in interest in science. This method of analysis revealed that most students that participated in this study experienced an increase in their interest in science. There were also interesting changes that occurred when the data is compared between categories of interest and academic groups.

Figure 1 shows that 30 of 61 students had their interest in science increase as a result of using the SEM and 22 of 61 students experienced a decrease in their interest in science. Nine students responded that their interest in science did not change. 


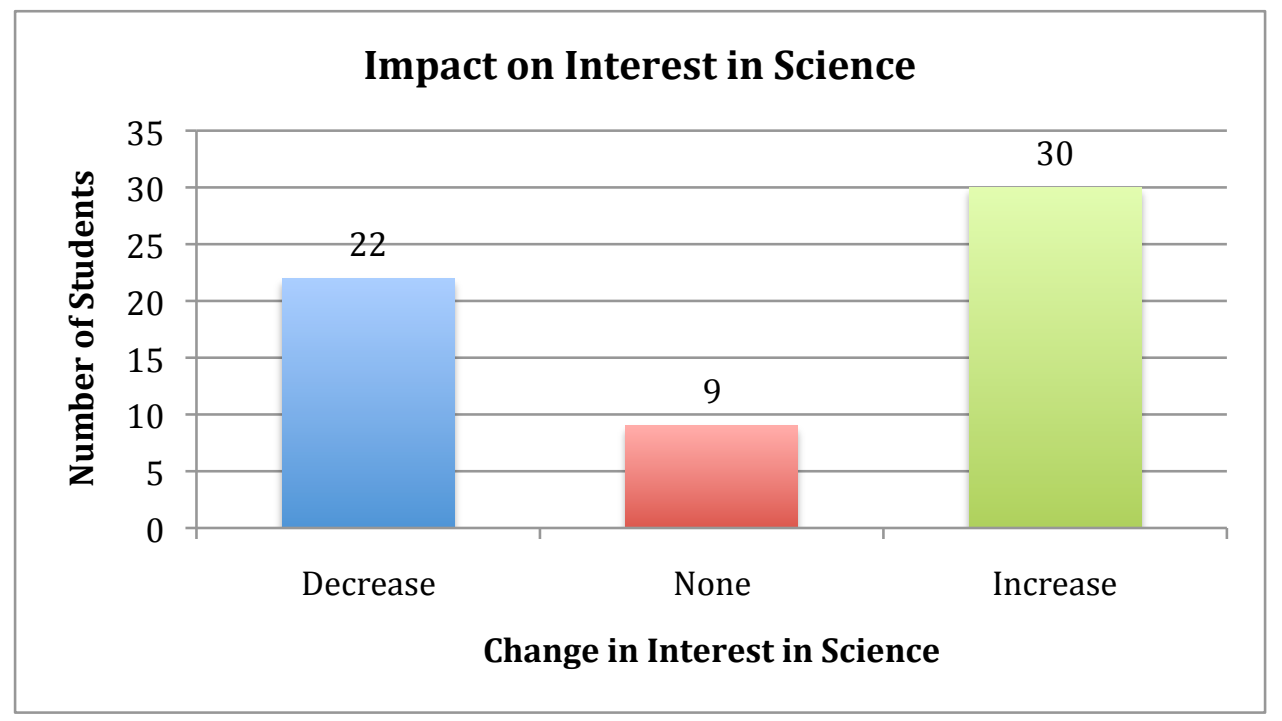

Figure 1: Comparison of the number of students who experienced different effects on their interest in science as a result of using an SEM.

This data shows that more students experienced an increase in their interest in science than experienced a decrease in their interest in science. In fact, almost $50 \%$ of students reported that their interest in science was higher after participating in the treatment.

The data was divided into three categories of statements to provide further detail on specific changes that occurred during the study. Statements 1 through 5 pertained to interest in science, statements 6 and 7 connected to interest in microscopes, and statements 8,9 , and 10 related to interest in nanoscience. 


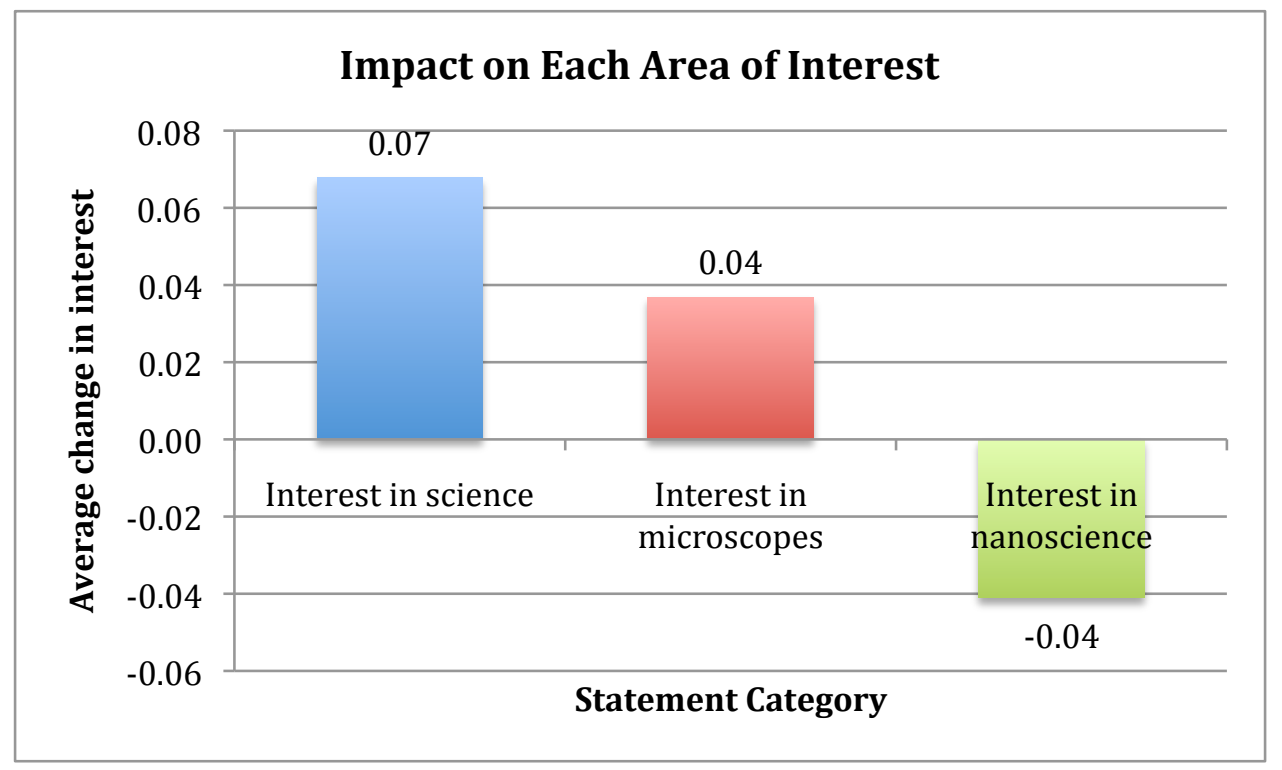

Figure 2: Average change in interest in each category analyzed.

Figure 2 shows that in general the participants became more interested in science but became less interested in nanoscience as a result of using the SEM.

To further explore the effect of using the SEM on students with different academic skills, participants were classified into four academic groups. Those students enrolled in the AP course were sorted into the 'Advanced Placement' group $(\mathrm{n}=9)$. The participants enrolled in the general Biology classes were separated into categories based on the previous quarter's final Biology grade. This classification is meant to reflect academic performance but may not be accurate to the current performance of each individual student. Nonetheless, 'High-performing' students earned between 92 and 100 percent during the last quarter $(\mathrm{n}=17)$. Student in the 'middle-performing' group earned between 81 and 91 percent during the last quarter $(\mathrm{n}=19)$. And 'low-performing' 
students earned between 14 and 80 percent during the last quarter $(n=16)$. While this method allowed for aggregation of the students involved, it does not necessarily reflect their academic performance during the semester when data was collected or overall in their high school career.

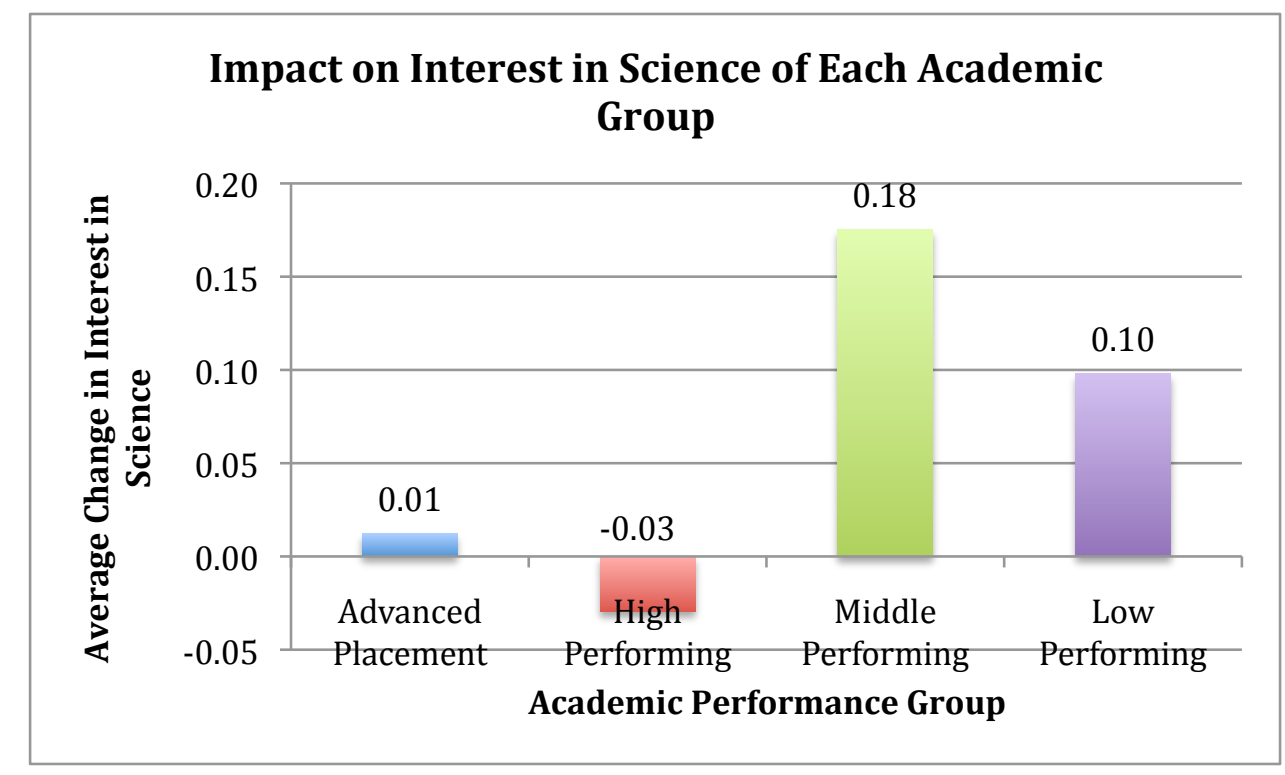

Figure 3: Average change on all statements disaggregated by academic performance category.

As seen in Figure 3, the middle-performing group experienced the largest increase in interest in science. The high-performing students experienced an overall decrease in their interest in science.

These four academic performance categories were examined further by analyzing the changes in responses within the three types of statements. Figure 4 shows the results of this disaggregation. 


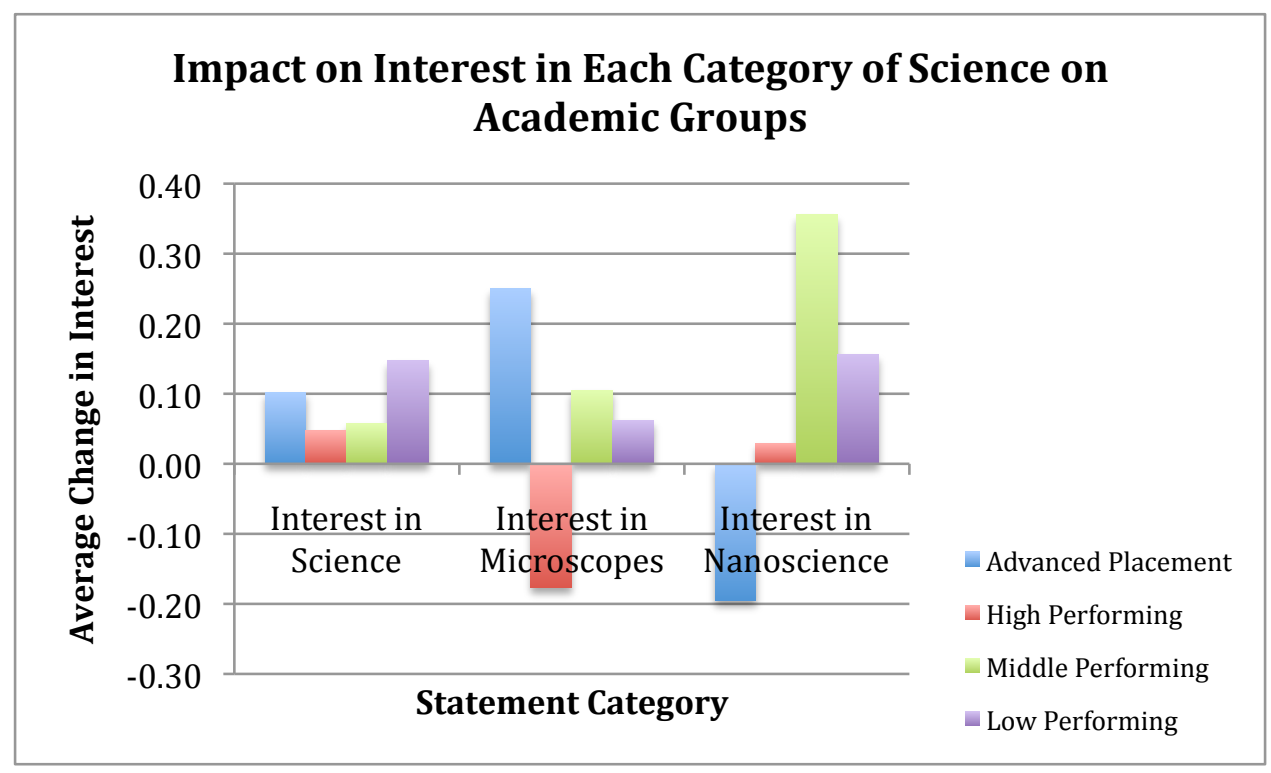

Figure 4: Comparison of change in agreement with each statement category between academically dissimilar groups of students.

Every group experienced an increase in agreement with the statements associated with interest in science. The 'middle-performing' students experienced a positive change in all three categories of statements and the largest increase in interest in nanotechnology.

\section{Experiences with the SEM}

The post survey included 5 additional statements that were not included on the pre-assessment. These statements addressed attitudes and perceptions regarding using the SEM. Due to the nature of the rating system, any rating under 2.5 (neutral) should be considered a disagreement with the statement. Figure 5 depicts the percent of students who agreed or strongly agreed with each of these statements compared with students who 
disagreed or strongly disagreed with each of these statements. The small numbers of students who wrote in a rating of 2.5 have been left out of the analysis below $(n=2$ on both statements 2 and 3 ).

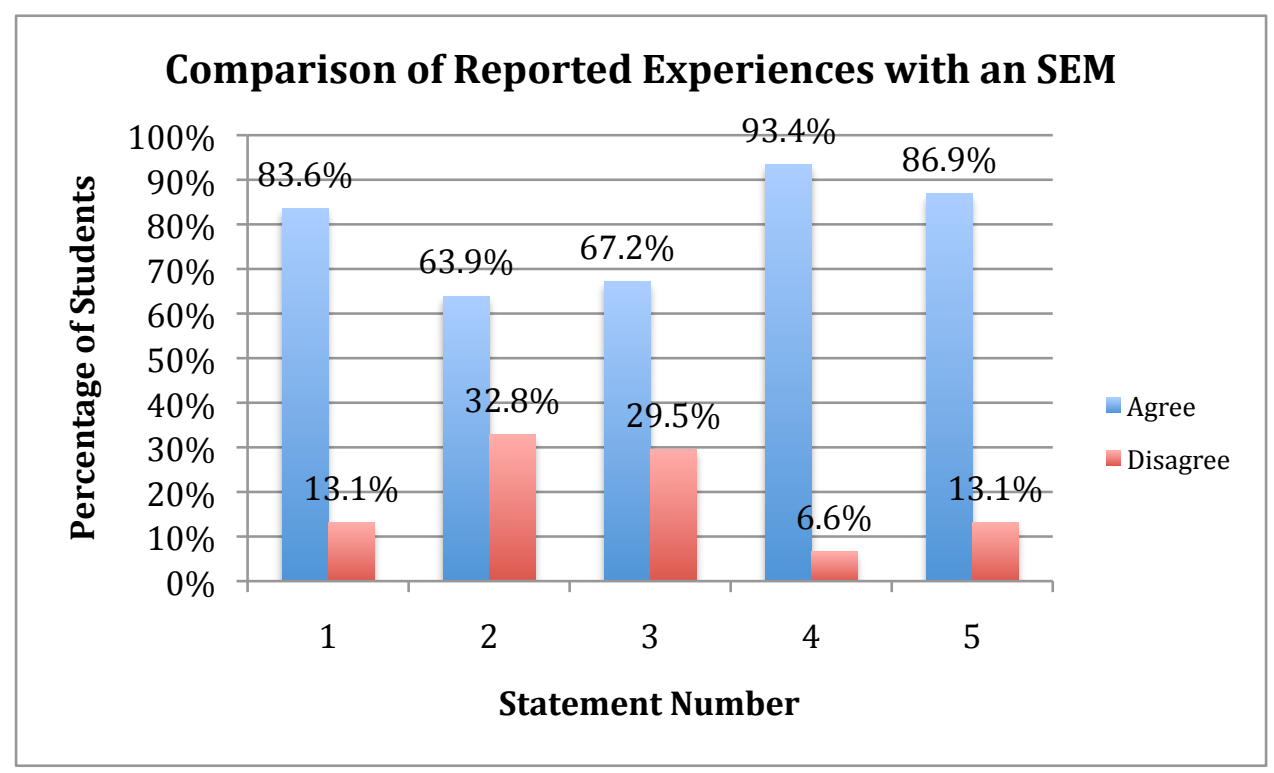

Figure 5: Comparison of percentage of students that agree with each additional post survey statement to the percent of students that disagree with each additional statement on the post survey.

The statement most highly agreed with (93.4\%) was statement number 4: "I can see how the SEM could be used in different types of science." Statement number 2 was the least likely to be agreed with (only $63.9 \%$ agreed with the statement): "Using the SEM got me excited about science." Another statement that received a relatively low rating when compared to the other statements was statement number 3: "Using the SEM helped me understand the concepts we were covering in my science class." 
The post survey SEM question responses were also disaggregated into academic performance groups to further explore experiences of each group (Figure 6).

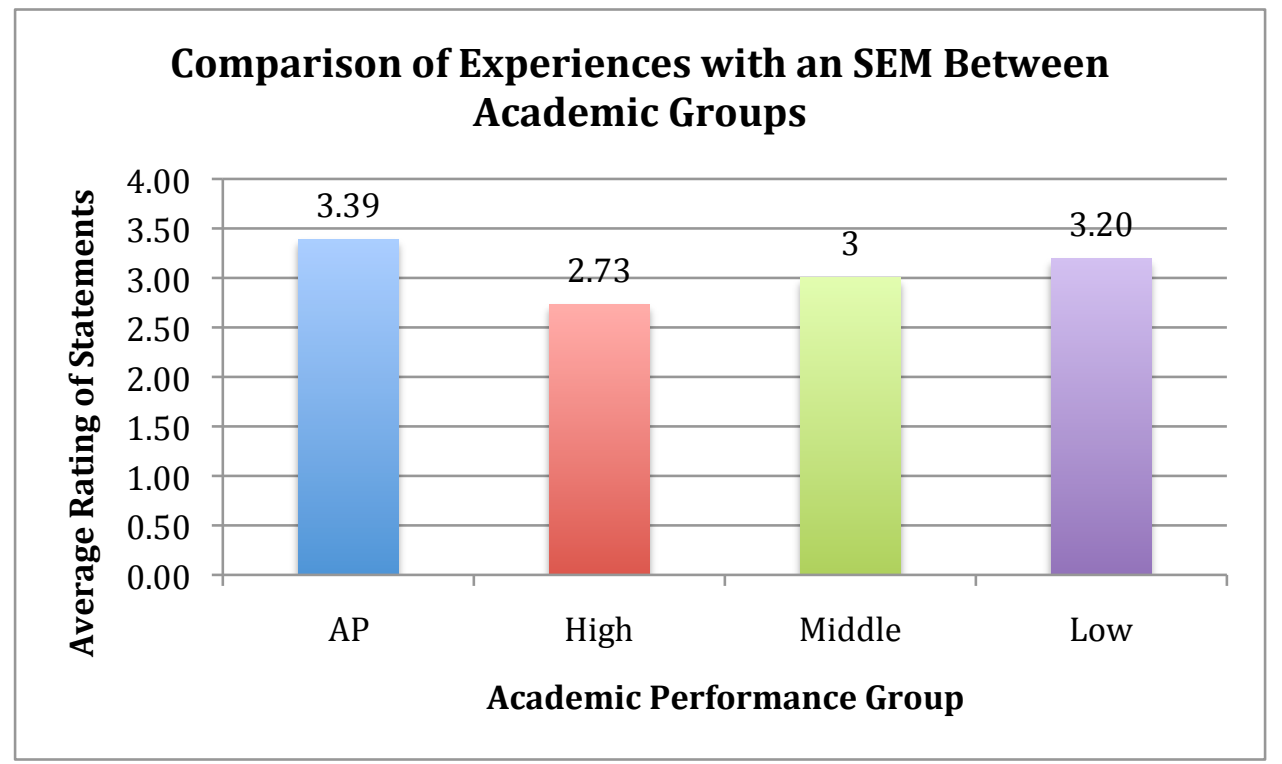

Figure 6: Comparison of average level of agreement with all post survey addition statements between academically dissimilar groups of students.

The results displayed in Figure 6 indicate there was some difference in the experiences of the various academic performance groups. The 'Advanced Placement' group showed the highest level of agreement with the statements, followed by the general Biology 'low-performing' students. The 'high-performing' general Biology students reported the lowest level of agreement with the statements on the post survey about using the SEM.

\section{Case Studies}


The following section provides a detailed account of the experiences of 7 students who were chosen to participate in the interview sessions. Three students from each academic performance level (high, middle, and low) were randomly chosen as case study

participants. Each participating student was assigned a random number that was recorded on his or her post survey. The surveys were separated into the four academic groups. Each group was spread out, face down and three papers were chosen at random to determine the students that would participate in the interviews. Due to time constraints, no Advanced Placement students were interviewed. Additionally, of the General Biology students, only seven of the participants completed all necessary data collection surveys and were included in this part of the study. All names have been replaced in order to maintain confidentiality. Their stories are described below and separated into the three academic levels.

\title{
High-Performing Students
}

\author{
Abbi ${ }^{1}$ \\ Abbi was eager and proactive when it came to spending time with the SEM and \\ produced a high-quality project displaying her work. On the pre and post surveys she \\ showed an average increase of 0.28 . This equates to a roughly $7 \%$ increase in interest in \\ science.
}


On the additional post survey statements Abbi agreed and strongly agreed with all but one statement: "I can see how the SEM could be used in different types of science." However, she agreed with the statements: "Learning how to use the SEM was interesting" and "Using the SEM helped me understand the concepts we were covering in my science class" and strongly agreed with the statements "Using the SEM got me excited about nanoscience" and "I enjoyed using the SEM." The open response question on this survey asked students to explain their rating of this final statement. She responded to this by writing "it's fun to learn about science, I like it."

The one-on-one interview revealed more about this student's interests and feelings about science and the SEM. When asked whether she had considered a career in the science she explained that during the last school year one of her friends would tell her about the things he was learning in his Biology class and she thought it would be interesting to do genetic experiments with new species and create transgenic organisms.

Abbi was less confident with her answer to the next question that addressed whether the SEM helped her learn the content. To this she replied with an unsure "yes" and indicated that it let her see the mutations on the fruit fly in detail.

When asked whether the SEM got her more interested in science she also agreed and specified that it showed her how people discovered and explored things in science.

The last two questions in the interview asked students about most positive parts of the experience and the parts that need improvement. This student's favorite part of using the SEM was being able to see things that you can't normally see. Her suggested improvement was to be able to look at a wider variety of specimens under the SEM. 
This case study is an example of a student that is highly interested in life science and received the most benefit by exploring how life science discoveries are made. She enjoyed seeing the abstract ideas discussed in life science classes manifest in real organisms that she could interact with personally. This student reported an overall positive influence on her interest in science as a result of using the SEM.

\section{Ellie $^{1}$}

Ellie displays a scientific way of thinking but does not seem to be particularly interested in life science. On the pre and post survey she showed a slight increase in science with an average change of 0.28 .

On the post survey questions about the SEM this student agreed with all statements and strongly agreed with statements 4 and 5 ("I can see how the SEM could be used in different types of science" and "I enjoyed using the SEM"). When asked to explain her rating of statement number 5, she responded "I am already interested in science, so it was nice to get to use more advanced equipment."

The one-on-one interview further reveals this student's focus on the technology of the SEM. When asked whether she had considered a career in science she replied with an excited "yes!" She explained that she is most interested in astrophysics or astronomy, her family is very "science-centric," and she has loved science from a very early age.

Despite this obvious interest in science, she did not think that the SEM helped her learn the material any better than an activity without the SEM would have. She felt that 
she already understood the material so the SEM project did not help to build her understanding.

When asked if the SEM got her more interested in science she replied 'no.' She further clarified that she enjoyed the access to the advanced technology but the experience did not necessarily change her interest in science, because she was already so interested in the topic.

When asked what she would like to change about the experience the only suggestion she had was for the tool to not experience so many technical difficulties.

This case study is an example of a 'high-performing' student who is highly interested in sciences other than life science. The most positive part of the experience was learning how to use and having access to highly advanced technology. Overall, this student experienced a positive impact on her interest in science as a result of using the SEM.

\section{Charles $^{1}$}

Charles is highly engaged and strives for excellence. He is one of the few $9^{\text {th }}$ grade students in the AP Biology class. He wrote a very detailed paper as a part of his project with the SEM. He was one of the few students that used the SEM twice due to technical difficulties during his first attempt. This student showed a 5.5\% increase in interest in science as a result of using the SEM. 
On the post assessment statements about the SEM he agreed or strongly agreed with all of the statements except for statement number 3: "Using the SEM helped me understand the concepts we were covering." His comment on the open response question reiterates the particular interests pointed out in the ratings he chose for the statements: "Looking at tiny things is awesome!"

This individual is interested in a career in science but could not give much detail into which field or why he would like to pursue a career in science. He simply added that it's "interesting."

When the content learned during the study was addressed the student provided more insight into his answer on the post assessment SEM questions. He explained that he already knew the content and the SEM just helped him look at the fly so this did not help him understand the content any better than if he hadn't used the SEM.

Charles strongly agreed that this experience got him interested in science. He responded with an enthusiastic "Yes! It was really cool!" when asked if using the SEM got him excited about nanoscience. A further inquisition revealed that he really enjoyed being able to see very small things.

He did not provide much contribution on what he would like to change about the experience. He added that he already knew content so the project did not help him in this sense. He also commented that he enjoyed using the Image J program, a photo-editing software commonly used to alter images produced by SEMs, to manipulate his images and that learning how the tool works was "cool." 
Charles is an example of a young student in a science course who is intrigued by science and still open to a career in science. He enjoyed the experience of using the SEM but it did not help him understand the content any clearer. The technical aspects of the experiences and exploring the nano-world caught his attention.

\section{Middle-Performing Students}

\section{Jeremy $^{1}$}

Jeremy shows a great interest in life science and particularly the human body. This student used the SEM but did not complete the required assignment. The data collected on this student's interest in science shows a slight increase during the study. The average change in rating of the statements on the pre and post survey for this student was an increase 0.11 . This is equates to a $2.75 \%$ increase in interest in science.

On the post survey SEM-related questions the student rated all statements with a 3 (agree) except statement number 2: "Using the SEM got me excited about nanoscience" which he rated as a 2, disagree. On the open response question he added the comment: "I like the SEM but it wasn't as interesting as I had hoped."

When asked whether he had ever considered a career in science, he explained that medical research has been an interest because his family has a history of cancer and he would like to do something in his career to help other families plagued by these diseases.

This student did not believe that using the SEM helped him learn the content better than if he hadn't used the SEM. He did not apply the images seen in the 
microscopes to the scientific concepts at hand. He reported that he "saw the bug really close" but it did not tell him anything about genetics.

He did agree when asked whether the SEM got him excited about science or more interested in the material. But, he was quick to include that the experience was not what he was hoping for, he explained that he had been hoping for "more colors, it was just gray. But the pictures were really cool that I got. I liked the optical one, the optical scope better." He also indicated that his favorite part of using the SEM was "Being able to see the organs up close. Being able to see things you can't see with your bare eye."

At the end of the interview he added that he would have liked to use the microscope to look inside of something, to look at an organ. This response clearly stems from his interest in anatomy and physiology.

Jeremy is an example of a middle-performing student with an interest in the medical field and anatomy. He was disappointed in his experience using the SEM because it did not allow him to explore his interests in particular. He enjoyed the experience and did show small increase in interest in science, but was expecting to use the tool outside of its capabilities.

\section{Low-Performing Students}

\section{Joey $^{1}$}

Joey attends class regularly but often does not complete assignments. He enjoys the hands-on activities and labs in the class but does not keep up with the pace of the 
course. He did complete the project assigned with the SEM and produced a PowerPoint presentation after an extension of time was granted. This student showed a large change in interest in science with an average increase of 0.58 . This equates to a $14.5 \%$ increase in interest in science as a result of using the SEM.

On the post assessment questions about using the SEM he agreed and strongly agreed with all statements except number 3: "Using the SEM helped me understand the concepts we were covering in my science class." He strongly disagreed with this statement.

In the interview this student revealed that he had been interested in Marine Biology as a future career but had been discouraged by the rigor of this course. He added that he did not realize that a career in Marine Biology would require so much of him.

Although he strongly disagreed with the statement on the post-assessment survey, in the interview this student said that he thought using the SEM helped him understand the content better because he was able to see the mutation manifest in a physical form.

He agreed that using the SEM got him interested in science. He supplemented this by expressing his interest in the technology: “...it's really cool how technology can do that... and take images of stuff like that that we could never take before." He accompanied this interest in the technology with his answer to the next question: "What did you enjoy most about using the SEM?" Saying that he enjoyed the clarity of the images and being able to see the mutations on flies with such great detail.

This student's suggestion for improvements to this project consisted of giving students more time to use the SEM. 
Joey is an example of a low-achieving student who is intrigued by science but overwhelmed by the sheer amount of knowledge required to understand the topic. $\mathrm{He}$ enjoyed using the technology to see detailed images of genetic mutations.

\section{Vanessa $^{1}$}

Vanessa is a "low-performing" student who receives ELL services and who had many medical problems during the term, causing her to fall behind in both understanding and grades. She did not complete the project assigned and did not complete the alternate provided. She is one of the three $11^{\text {th }}$ grade students in the class. This student showed a small change in her interest in science with a $2.75 \%$ increase.

On her post assessment questionnaire, she agreed and strongly agreed with all of the statements about using the SEM. She supplemented these ratings with the comment: "It was extremely fun to see the species in a more vivid picture and in more detail picture...[sic]"

During the interview this student explained that she had considered a career in science but is more interested in working in criminal justice.

She confidently agreed that using the SEM helped her understand the content by being able to see the physical structures on the fly. It also helped her to visualize the mutations so that she could apply them to the project assigned.

For this student, using the SEM got her more interested in science because she was able to see an insect at a different level. She explained that when she looks at an 
insect she sees the object as a whole, strange thing, but the SEM showed her the complexity of the structures that make up that object. She really enjoyed taking the pictures and searching around for the different structures on the fly. Her suggestion for improving the project was to be able to look at more species.

Vanessa is an example of a "low-achieving" student who is interested in science but does not want to pursue it as a career. This project made her appreciate the complexity of an organism often taken for granted. She would have liked to expand this appreciation by viewing a diversity of organisms under the SEM.

\section{Tiana $^{1}$}

Tiana is interested in science and contributes to conversations but does not attend class regularly or put in the effort required to pass the exams. She did complete the project, but her partner was very displeased with her level of contribution. Her average change in agreement with the statements on the pre and post surveys was -0.58 . This is a $14.5 \%$ decrease in interest in science.

Her responses to the post assessment questions about the SEM do not provide many clues into why this decrease occurred. She agreed and strongly agreed with all of the statements. The statements she rated as a 3 (agree) included statements number 2 ("Using the SEM got me excited about science") and number 5 ("I enjoyed using the SEM"). These two statements directly address interest in using the SEM. The comment she provided on this survey stated: "I thought it was rather fun to use and operate I just wish we could have done more with it." 
In the interview Tiana revealed that she is interested in pursuing a career in the medical field -- particularly physical therapy. She mentioned that this is a family trade and that it pays fairly well.

Tiana agreed that using the SEM helped her understand the content because it allowed her to see the traits that we were studying. She also agreed that the SEM got her more interested in the material because it allowed her access to a "high-tech machine" that the school wouldn't normally have. She added that it was a pretty expensive machine that she was afraid to touch.

This student's favorite part of using the SEM was being able to see the fly wing that had broken in the mounting process. She also enjoyed taking the pictures.

When asked what she would suggest to improve the project she quickly stated "more time." She explained that she felt she was rushed. She also would like to see the SEM used for more than just one topic in the class.

Tiana is an example of a low-achieving student who experienced a decrease in her interest in science as a result of using the SEM. She enjoyed the access to the advanced technology but did not find the experience intriguing.

\section{Summary}

In order to draw meaningful conclusions from the data gathered during the interviews, a table has been constructed that condenses the results. 
Table 5: Summary of data gathered during qualitative interviews with seven participants

\begin{tabular}{|c|c|c|c|c|c|}
\hline $\begin{array}{c}\text { Student } \\
\text { Name }\end{array}$ & $\begin{array}{c}\text { Academic } \\
\text { Group } \\
\text { (High, Mid, } \\
\text { Low) }\end{array}$ & $\begin{array}{c}\text { Increase } \\
\text { content } \\
\text { knowledge* } \\
\text { (Yes or No) }\end{array}$ & $\begin{array}{c}\text { Increase } \\
\text { Interest* } \\
\text { (Yes or } \\
\text { No) }\end{array}$ & $\begin{array}{c}\text { Change in } \\
\text { Interest } \\
\text { Quantity/ } \\
\text { Percent) }\end{array}$ & $\begin{array}{c}\text { Suggestion } \\
\text { for } \\
\text { improvement }\end{array}$ \\
\hline Tiana & Low & Yes & Yes & $-.58 /-14.5 \%$ & $\begin{array}{c}\text { Increase } \\
\text { access time to } \\
\text { the tool }\end{array}$ \\
\hline Vanessa & Low & Yes & Yes & $.11 / 2.75 \%$ & $\begin{array}{c}\text { Observe a } \\
\text { wider variety } \\
\text { of specimens }\end{array}$ \\
\hline Joey & Low & N/A & Yes & $.58 / 14.5 \%$ & $\begin{array}{c}\text { Increase } \\
\text { access time to } \\
\text { the tool }\end{array}$ \\
\hline Charles & High & No & Yes & $.11 / 2.75 \%$ & $\begin{array}{c}\text { Observe } \\
\text { internal } \\
\text { organs of } \\
\text { specimens }\end{array}$ \\
\hline Ellie & High & No & Yes & $.22 / 5.5 \%$ & $\begin{array}{c}\text { None } \\
\text { Mid }\end{array}$ \\
& & & & & $\begin{array}{c}\text { Reduce } \\
\text { frequency of } \\
\text { technical } \\
\text { difficulties }\end{array}$ \\
\hline Abbi & High & Yes & Yes & $.28 / 7 \%$ & $\begin{array}{c}\text { Observe a } \\
\text { wider variety } \\
\text { of specimens }\end{array}$ \\
\hline
\end{tabular}

*Perception of changes within the individual made by the individual determined through answers to interview questions 2 and 3.

The summary presented in Table 5 clearly states three improvements that can be made to the students' experiences with the SEM: 1) Increase the variety of specimens observed, 2) Increase the amount of access time, and 3) Reduce the frequency of technical difficulties. Another common aspect that stands out is that six of the seven interviewees stated that using the SEM did get them more interested in science. However, only three participants said that it helped them learn the content. 


\section{Chapter 5: Discussion}

The overarching goal of this study was to increase students' interest in science. The purpose of this goal is that ultimately an interest in science is likely to lead to an individual choosing a career in a STEM field (Simpkins et al., 2006; Lubben et al., 2010). According to published literature, nanoscience is an effective tool for achieving this goal (Hsi et al., 2006). This study was guided by the research question: Does allowing high school students access to nanotechnology via the use of a tabletop Scanning Electron Microscope increase their interest in science? To answer this question, the researcher included a tabletop Scanning Electron Microscope (SEM) borrowed from the grantfunded organization Project NANO in curriculum units in an AP Biology and four General Biology classes. The author's hypothesis was that allowing students access to nanotechnology via the SEM would increase their interest in science. The implication of the results of this study is that the evidence gathered supports the hypothesis that nanoscience (implemented through one-time use of a tabletop SEM) is an effective tool to increase interest in STEM fields.

\section{Analysis of All Participants}

Examination of this study produced some interesting findings. Overall, more students experienced an increase in their interest in science than experienced a decrease or no change in their interest in science. This result shows that in general, using an SEM can increase a student's interest in science. 
Analysis of the specific categories of interest in science (science, microscopes, and nanoscience) showed that the participants in this study experienced a decrease in their interest in nanoscience and an increase in their interest in science in general. These results were quite unexpected considering the focus of this study was the introduction of nanoscience to high school students. This result suggests that alterations to the method of presenting the nanoscience discipline and tools are needed to increase student interest in these categories. Curriculum that is specific to nanoscience and highlights the utility of the scientific tool at hand may produce more positive results.

Analysis of the post survey regarding experiences with the SEM revealed several positive results. More than $60 \%$ of the students agreed with all of the statements on the post survey. Over $90 \%$ of students agreed with statement number 4: "I could see how the SEM could be used in different types of science." This may indicate that direct instruction on the utility of the SEM is an important component of incorporation into a classroom. The statement that was least likely to be agreed with was statement number 2: "Using the SEM got me excited about science." None of the students interviewed said that using the SEM got them excited about science, yet all said that it got them interested in science. The connection of these two data collection methods suggests that excitement is not the emotion evoked by the SEM but rather interest, which was the ultimate goal of this study.

\section{Analysis of Academic Groups}


Other interesting results of this study came from the differences in experiences of students at different academic levels. Students at all academic levels experienced an increase in science in general. Additionally, students in both the 'middle-performing' and 'low-performing' groups experienced an increase in interest in all of the interest in science statement categories. Quite unexpectedly, students in the high-performing group experienced the lowest overall increase in interest in science. This group also reported the lowest level of agreement with the statements on the portion of the post survey that specifically addressed experiences with the SEM. As suggested in the interview portion of the data collection, this may have been a result of previous familiarity with the topics covered during the unit that included the SEM. These students also desired more time to use and explore the capabilities of the SEM. Informal, unrecorded observations suggest that this recommendation may have stemmed from a learning curve associated with a new scientific tool. Students have many opportunities to master the other tools used in a science classroom such as balances, graduated cylinders, and compound light microscopes. But, with this tool they were only allowed a few minutes to familiarize themselves with it and utilize its capabilities. It is likely that this is not enough exposure for students to realize the significance of the SEM and use it to improve content knowledge.

An additional outcome discovered in analysis of this study was the decrease in interest in nanoscience seen in the AP Biology group. It is likely that this consequence was a result of the minimal information on nanoscience that this group received during the study. This group did not receive any direct instruction on the nanoscience discipline 
or how nano-tools are useful in everyday life. This lack of knowledge may have left the AP biology group thinking of the SEM as the full scope of the nanoscience discipline. While this is plausible, it is difficult to determine the actual cause of this change because no AP students were interviewed as part of the data collection.

\section{Chapter 6: Limitations and Recommendations}

The evidence gathered in this study does support the current published research on the topic of using nanoscience to increase students' interest in science. However, the results may have been affected by a number of limitations to this study. These limitations are a direct threat to the generalizability of this study. This section addresses those limitations along with recommended improvements to SEM use in the classroom. These improvements have been compiled through suggestions from the participants of the study and interpretation of the data collected as a part of the study.

This study had several limitations that are important to consider when discussing the results. The most significant of these limitations is the nature of the research itself. This action research project was limited to the small number of classes and students available to the researcher. This limitation prevented any statistical analysis from being useful to draw conclusions from the data. Exploring this issue with larger groups of students may produce different results.

The students were divided into 'academic groups' using a method that may not necessarily reflect their current performance or comprehension. The non-AP students were divided into groups using their grade from the previous semester of Biology. Many 
personal factors could have changed between the time when this grade was recorded and when then data was collected. This method of categorization may have altered the analysis of the results and the data collected during the interview process.

Also, students who participated in this study indicated that they required more time with the SEM. Most students were able to use the SEM once for less than twenty minutes. This likely had a significant affect on the results of this study, as there is a learning curve that comes along with learning to use any new piece of equipment. More time to master the tool would allow students to avoid technical difficulties and move beyond the novice stage to the mastery stage where real, significant learning can take place. The time constraints also limited the number of specimens students were able to observe. All students only observed one type of mutation on the same species of fruit fly. Allowing students multiple uses, a longer time frame, and a variety of specimens may produce different results.

An additional significant limitation to this study was the incompatibility of the curriculum and the SEM as an observation tool. In a Biology course the SEM is best used for correlating structure and function. The topic covered during the unit that was a part of this study was Genetics. The functional structures of genetics (DNA and chromosomes) are not visible with the SEM. Therefore; students were required to observe the result of genetic mutations. As indicated by the interview sessions and the low level of agreement with the statement on the post survey that addressed learning of content, many students were unable to connect the observed structures to the function of DNA and genes. A secondary factor that may have contributed to this result is the nature of the assignment 
associated with using the SEM. The project assigned had a very different structure than the assignments previously used in the course; it was very open-ended and required a large amount of independent work. Based on the instructor's observations, these types of assignments can be difficult for students who have not have previous exposure to them. A curriculum topic in which the SEM is more useful for observation purposes and an assignment type that students are more comfortable with will likely produce more positive results in changing students' interest in science.

Another limitation was the differential treatments of the AP and General Biology groups. The AP Biology group did not receive direct instruction on nanoscience. Equal instruction of both groups would increase the validity of the results produced in this study. Due to time constraints, AP Biology students were also not interviewed as part of the data collection. The addition of this academic group to the data set could provide more insight into the experiences of advanced students.

\section{Chapter 7: Further Research}

Due to the limited nature of this study, it would be beneficial to carry out the same research in a different setting using another set of participants and a more appropriate curriculum topic. Doing so would provide additional data to support or refute the hypothesis addressed in this study.

Several additional questions have also arisen as a result of this study. Such as: How much time is appropriate for using this tool? Is direct instruction on nanoscience required to spark an interest in the topic? What types of assignments, topics, and 
specimens are most beneficial when using the SEM in a high school classroom? These questions should be explored as extensions of the data collected during this study. This study showed that many students could have their interest in science decrease as a result of using an SEM. Further investigation into these students' experiences would provide valuable insight into possible methods to prevent a decrease in interest. 


\section{References}

European Commission. (2005). Nanosciences and nanotechnologies: An action plan for Europe 2005-2009. Retrieved September 27, 2011, from

http://cordis .europa.eu/nanotechnology/actionplan.htm

German Federal Ministry of Education and Research (2011). Nanotechnology: A future technology with visions. Retrieved September 27, 2011, from

http://www.bmbf.de/en/nanotechnologie.php

Gonzales, P., Guzman, J. C., Partelow, L., Pahlke, E., Jocelyn, L., Kastberg, D., et al. (2004). Highlights from the Trends in International Mathematics and Science Study (TIMSS) 2003 (NCES 2005 - 005). Washington, DC: U.S. Government Printing Office.

Hingant, B., \& Albe, V. (2010, September). Nanosciences and nanotechnologies learning and teaching in secondary education: a review of literature. Studies in Science Education, 46(2), 121-152.

Hsi, S., Sabelli, N., Krajcik, J., Tinker, R., \& Ellenbogen, K. (2006, June). Learning at the nanoscale: Research questions that the rapidly evolving interdisciplinarity of science poses for the learning sciences. Innovative Session, 7th International Conference of the Learning Sciences, Bloomington, IN. Retrieved September 27, 2011, from http://nanosense.org/documents/papers/ICLS2006HsiSabelli.pdf

Jones, M. G., Andre, T., Superfine, R., \& Taylor, R. (2003). Learning at the Nanoscale: The Impact of Students' Use of Remote Microscopy on Concepts of Viruses, Scale, and Microscopy. Journal of Research in Science Teaching, 40(3), 303-322.

Kesidou, S., \& Roseman, J. E. (2002). How well do middle school science programs measure up? Findings from Project 2061's curriculum review. Journal of Research in Science Teaching, 39, 522 - 549.

National Nanotechnology Initiative, The (NNI). (2011). Strategic Plan. Retrieved September 27, 2011, from, http://www.nano.gov/node/581

Nanotechnology Researchers Network Center of Japan (2006). Nanotech school. Retrieved September 27, 2011, from http://www.nanonet.go.jp/english/school/

National Science Board. (2010). Chapter 7: Science and technology: Public attitudes and public understanding. Science and Engineering Indicators-2010. Arlington, VA: National Science Foundation. Retrieved September 27, 2011, from http://www.nsf.gov/statistics/seind10/c7/c7h.htm 
National Science and Technology Council Committee on Technology \& Subcommittee on Nanoscale Science, Engineering, and Technology (2005, March). The National Nanotechnology Initiative: Research and development leading to a revolution in technology and industry. Arlington, VA: National Nanotechnology Coordination Office.

Oregon Department of Education. (2011, October 6). 2010-2011 School Report Card: Estacada High School (Estacada High School 135). Retrieved from http://www.ode.state.or.us/data/reportcard/reports.aspx

Roco, M. C. (2003). Converging science and technology at the nanoscale: Opportunities for education and training. Focus on Nanotechnology, 21(10), 1247 - 1249.

Treder, M. (2004). Jolt to the system: the transformative impact of nanotechnology. Retrieved September 30, 2011 from www .crnano.org/Speech\%20-\%20Troy\%20$\% 20$ Mike\%20Treder,\%20CRN.ppt 
Appendix A: Instruments

Opinion Survey Questions

\begin{tabular}{|c|c|c|c|c|}
\hline $\begin{array}{l}\text { Survey Question: } \\
\text { Please circle one number }\end{array}$ & $\begin{array}{l}\text { Agree } \\
\text { Strongly }\end{array}$ & Agree & Disagree & $\begin{array}{l}\text { Disagree } \\
\text { Strongly }\end{array}$ \\
\hline 1. I find science interesting. & 4 & 3 & 2 & 1 \\
\hline $\begin{array}{l}\text { 2. I look forward to the activities we do in } \\
\text { science class. }\end{array}$ & 4 & 3 & 2 & 1 \\
\hline $\begin{array}{l}\text { 3. I enjoy learning about and exploring } \\
\text { science outside of school. }\end{array}$ & 4 & 3 & 2 & 1 \\
\hline $\begin{array}{l}\text { 4. I talk with my friends or family about } \\
\text { the things we discuss in science class. }\end{array}$ & 4 & 3 & 2 & 1 \\
\hline $\begin{array}{l}\text { 5. I plan to take more science classes than } \\
\text { are required to graduate high school. }\end{array}$ & 4 & 3 & 2 & 1 \\
\hline $\begin{array}{l}\text { 6. Looking at things using microscopes } \\
\text { gets me thinking about other things around } \\
\text { me that are too small to see without a } \\
\text { microscope. }\end{array}$ & 4 & 3 & 2 & 1 \\
\hline $\begin{array}{l}\text { 7. I would enjoy seeing things that are too } \\
\text { small for our class set of microscopes to } \\
\text { see. }\end{array}$ & 4 & 3 & 2 & 1 \\
\hline $\begin{array}{l}\text { 8. I am interested to see how the medical } \\
\text { field will use micro-technology in the } \\
\text { future. }\end{array}$ & 4 & 3 & 2 & 1 \\
\hline $\begin{array}{l}\text { 9. I am interest to see how car } \\
\text { manufacturers will use micro-technology } \\
\text { in the future. }\end{array}$ & 4 & 3 & 2 & 1 \\
\hline $\begin{array}{l}\text { 10. I am interested to see how the } \\
\text { electronics industry will use micro- } \\
\text { technology in the future. }\end{array}$ & 4 & 3 & 2 & 1 \\
\hline
\end{tabular}


Post Survey Additional Statements

\begin{tabular}{|l|lccc|}
\hline $\begin{array}{l}\text { Survey Question: } \\
\text { Please circle one number }\end{array}$ & $\begin{array}{l}\text { Agree } \\
\text { Strongly }\end{array}$ & Agree & Disagree & $\begin{array}{l}\text { Disagree } \\
\text { Strongly }\end{array}$ \\
\hline $\begin{array}{l}\text { 1. Learning how to use the SEM was } \\
\text { interesting }\end{array}$ & 4 & 3 & 2 & 1 \\
\hline $\begin{array}{l}\text { 2. Using the SEM got me excited about } \\
\text { nanoscience. }\end{array}$ & 4 & 3 & 2 & 1 \\
\hline $\begin{array}{l}\text { 3. Using the SEM helped me understand } \\
\text { the concepts we were covering in my } \\
\text { science class. }\end{array}$ & 4 & 3 & 2 & 1 \\
\hline $\begin{array}{l}\text { 4. I can see how the SEM could be used } \\
\text { in different types of science. }\end{array}$ & 4 & 3 & 2 & 1 \\
\hline 5. I enjoyed using the SEM. & 4 & & & \\
\hline
\end{tabular}

Please explain your rating for question number 5: 


\section{Interview Questions}

1. Have you ever considered a career in science as a possibility for your future? Why or why not?

2. Do you think that using the SEM helped you understand the topic of genetics better than if we hadn't used it?

3. Would you say that using the SEM got you excited about science or more interested in the material? Why or Why not?

4. What did you enjoy most about using the SEM?

5. What would you change about using the SEM in your classes? 


\section{Appendix B: Research Approval Documents}

\section{舟 Portland Sutete}

Human Subjects Research Review Committee Post Office Box $751 \quad 503-725-4288$ tel

Portland, Oregon 97207-0751 503-725-8170 fax

hsrrc@lists.pdx.edu

December 2, 2011

To: Leslie TenEyck

From: Mary Oschwald, HSRRC Chair

Re: $\quad$ HSRRC approval for your project titled, "Project Nano" (HSRRC Proposal \# 111960).

Dear Leslie,

In accordance with your request, the Human Subjects Research Review Committee has reviewed your proposal referenced above for compliance with PSU and DHHS policies and regulations covering the protection of human subjects. The Committee is satisfied that your provisions for protecting the rights and welfare of all subjects participating in the research are adequate, and your project is approved. Please note the following requirements:

Changes to Protocol: Any changes in the proposed study, whether to procedures, survey instruments, consent forms or cover letters, must be outlined and submitted to the Committee immediately. The proposed changes cannot be implemented before they have been reviewed and approved by the Committee.

Continuing Review: This approval will expire on December 2, 2012. It is the investigator's responsibility to ensure that a Continuing Review Report on the status of the project is submitted to the HSRRC two months before the expiration date, and that approval of the study is kept current. The Continuing Review Report is available at www.rsp.pdx.edu/compliance_human.php and in the Office of Research and Strategic Partnerships (RSP).

Adverse Reactions and/or Unanticipated Problems: If any adverse reactions or unanticipated problems occur as a result of this study, you are required to notify the Committee immediately. If the issue is serious, approval may be withdrawn pending an investigation by the Committee.

Completion of Study: Please notify the Committee as soon as your research has been completed. Study records, including protocols and signed consent forms for each participant, must be kept by the investigator in a secure location for three years following completion of the study (or per any requirements specified by the project's funding agency).

If you have questions or concerns, please contact the HSRRC in the Office of Research and Strategic Partnerships (RSP) at 503-725-4288, Market Center Building, Room 620.

\section{Cc: Liza Finkel}


Leslie TenEyck

Center for Science Education,

Portland State University

teneyckl@pdx.edu

503-341-8160

December 7, 2011

Estacada School District

Estacada High School

$355 \mathrm{NE} 6^{\text {th }}$ Ave.

Estacada, OR 97023

\section{To Whom It May Concern:}

I would like to propose a research project to be carried out at Estacada High School in Kate Dean's Biology classroom. I am currently student teaching under Ms. Dean and working on a Master's thesis. My thesis project, entitled Project NANO: Will allowing high school students to use research grade scanning electron microscopes increase their interest in science?, aims to increase student interest in the sciences by allowing them to use research-grade scanning electron microscopes. Project NANO, a grant-funded partnership between Portland State University and local high schools, will provide the microscopes used in this study. Pending permission, the dates of this study will be April $16^{\text {th }}, 2012$ to May $2^{\text {nd }}, 2012$. All four sections of Kate Dean's Biology students and her one section of AP Biology students will participate in the study, with the exception of those who opt out. So far, one hundred and five parents have agreed to allow their student to participate in the study, with only one parent requesting to opt out.

My university has approved my request to conduct research in your district. Attached is the Portland State University Internal Review Board's application for research. This application includes the letter that will be sent home for parents to approve their child's participation in the study. If you have any questions, please feel free to contact my research advisor, Liza Finkel (efinkel@pdx.edu), or myself. If you agree to allow this research to take place in your district/school, please sign the statement at the bottom of this page.

Sincerely,

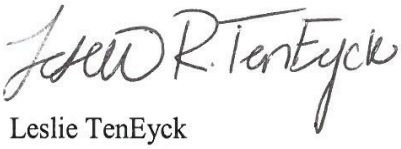

I, ScoH Sullivan, agree to allow Leslie R. TenEyck to carry out her Master's Thesis research in the district/school that I oversee. I have read and approve the procedures that will be a part of this study.

Signature:

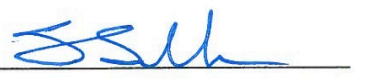

Title: Principal

Date: $4 / 4 / 12$ 


\section{Appendix C: Curriculum}

\section{SEM Project}

\section{ELS 9.1: I can identify Mendel's three principles and use them to evaluate monohybrid and dihybrid crosses}

\section{ELS 9.2: I can explain alternate forms of inheritance that contradict Mendel's findings.}

Task: You, a famous geneticist, have just discovered a new species! After analyzing the DNA and physical characteristics of this species you find some interesting things including a mutation that is commonly seen in fruit flies.

Describe your new species to your fellow scientists. To do this you will need to collect visual and written data on the fruit fly mutation (using the SEM, an optical scope, and the internet) and describe the physical and genetic characteristics of your new species.

1. Choose your choice of presentation type:
a. Powerpoint or Prezi to a panel of scientists
b. Poster for presentation at a scientific conference
c. Written scientific paper for submission to a scientific journal
d. Something else approved by your teacher

2. Your presentation should include the following sections:

Section 1: Background Research

- Choose one of the following mutations to research:

$\circ$ Vestigial Wings (messed up wings)

$\circ$ Miniature Wings (tiny wings)

$\circ$ Vestigial Wings (no wings)

- Bar Eyed (vertical bar-shaped eye)

o Forked Bristle (hairs are funky shaped)

o Antennapedia (leg-like antenna)

- Use the internet and resources on your teacher's website (insert website here) to research the following about the mutation:

$\circ$ A description of what the mutation looks like

○ How is the mutation inherited? (autosomal dominant, autosomal recessive, sexlinked, codominant, incomplete dominance, polygenic.)

o What chromosome does the mutation occur on?

Section 2: Observe your mutation

- Use the SEM to gather take pictures of the mutation on a fruit fly 
- Use the optical microscope to take pictures of the mutation on a fruit fly

- Use image J to edit one of the photos you took with the SEM, show a before and after

Section 3: Describe your new species

- Pretend that you are a scientist that just discovered a never-before-seen species. After sequencing its DNA, you notice it has a mutation commonly seen in fruit flies.

- Describe five characteristics of your new species. Your traits must meet the following requirements:

- Trait 1: The mutation you research as it appears in your new species

- Trait 2: A trait that is inherited codominantly or using incomplete dominance

- Trait 3: A trait that is inherited polygenically

- Trait 4: A trait that is sex-linked

- Trait 5: A trait that is on an autosome, pick whether its dominant or recessive

- Draw one male and one female of your new species

- Make sure that each one has a different variety of the five characteristics you described

Section 4: Your species' inheritance

- Pick one of the traits you described in section 3, carry out a monohybrid punnett square using that trait.

o Include the genotypic ratio (Homozygous dominant, to heterozygous, to homozygous recessive) of your offspring o Include the phenotypic ratio (affected, to not affected) of your offspring

- Pick two of the traits you described in section 3, carry out a dihybrid punnett square using those traits.

o Include the phenotypic ratio of your offspring

Section 5: Story Problems

- Use the traits you described in section three to create five genetics story problems involving your species. These should be formatted like the story problems we have been practicing in class.

o Be sure to include all of the information needed to solve the problem

$\circ$ Provide the solutions to your problems on a separate sheet 